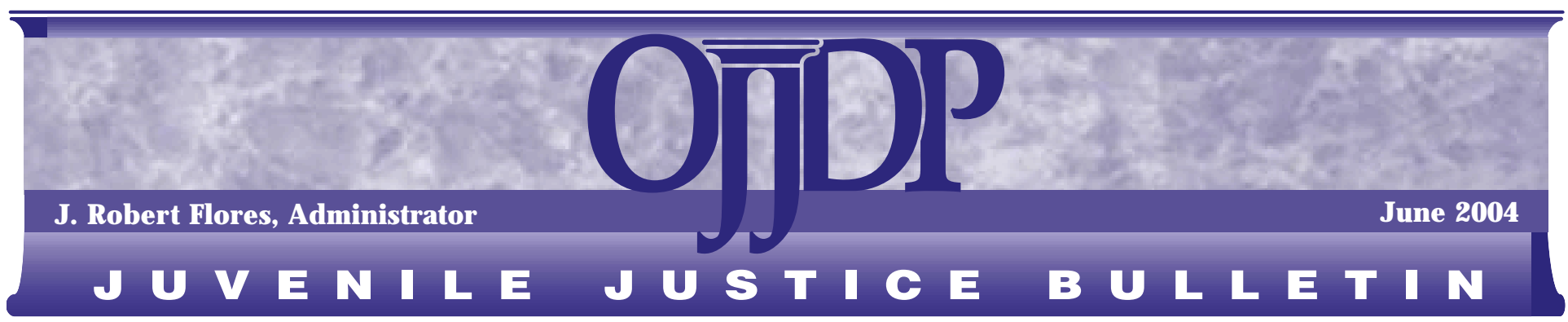

Office of J ustice Programs - Partnerships for Safer Communities • www.ojp.usdoj.gov

\title{
Detection and Prevalence of Substance Use Among Juvenile Detainees
}

\section{Gary M. McClelland, Linda A. Teplin, and Karen M. Abram}

Identifying and responding to juvenile substance use and abuse are central to the mission of the juvenile justice system. The reasons are clear:

- Of the approximately 2.4 million juvenile arrests each year, more than 203,000 are for drug charges (Snyder, 2002). As of October 27, 1999, nearly 109,000 juvenile offenders were in custody in juvenile residential placement facilities; approximately 9,880 of these youth (9 percent) were held for drug charges (Sickmund, forthcoming).

- Many youth in the justice system have a substance use disorder (Atkins et al., 1999; Gray and Wish, 1998; Marsteller et al., 1997; Teplin et al., 2002), and many more regularly use illicit substances (Crowe, 1998; Dembo et al., 1993, 1999; Feucht, Stephens, and Walker, 1994; Kang, Magura, and Shapiro, 1994).

Juveniles are not likely to be candid about their use of drugs and, like adult detainees, juveniles in detention are especially reticent. Juvenile justice authorities should, therefore, be prepared to identify substance use problems among detainees and to use this information to provide treatment and diversion (Gray and Wish, 1998;
Crowe, 1998; Bilchik, 1998; Cocozza, 1992; Teplin, 2001).

The Northwestern J uvenile Project is a study of 1,829 juveniles sampled from intake at the Cook County Juvenile Temporary Detention Center in Chicago, IL. Researchers gathered extensive self-report data on substance use and collected urine samples for drug analysis. This Bulletin describes the self-report and urinalysis findings, with the goal of providing practical guidance for juvenile justice policymakers and administrators planning drug detection and treatment programs.

The Bulletin has four sections. The first presents background information on the effects of substance use and abuse on adolescent development, demonstrating the significant role of this factor in delinquency. The second section reviews literature on the measurement of illicit substance use in detained and securely confined juvenile populations and assesses the state of the science. The third section presents empirical findings from the Northwestern Juvenile Project on the relative merits of self-report and urinalysis measures and on the prevalence of illicit substance use among detained juveniles by age, gender,

\section{A Message From OJJ DP}

Research indicates that many juveniles who enter detention facilities have used drugs. To provide effective deterrence and treatment for such youth, juvenile justice authorities need reliable information on substance use problems. While questioning detainees about their drug use does not necessarily produce valid results, alternative methods of testing for drugs also have shortcomings.

Using data from the Northwestern Juvenile Project's study of high-risk youth detained in Cook County, IL, the authors of this Bulletin assess two widely used measures of drug use: self-reporting and urinalysis. Their assessment covers a range of substances but focuses on cannabis and cocaine, the drugs most commonly used by juvenile detainees.

The study confirms a high rate of drug use among juvenile detainees and identifies detainees who require special attention. The authors conclude that because cannabis use is so common and often leads to more serious drug use, most youth entering detention can be considered at risk of developing substance abuse problems. The study's findings indicate that the best approach to detecting substance abuse is to combine self-reporting with urinalysis and also use other resources such as treatment and drug arrest histories and information from families and schools. 
race/ethnicity, and type of substance. The final section discusses the implications of these findings.

The authors conclude that presently there is no single reliable method for detecting substance use and abuse among juvenile detainees. The best approach to reliable assessment uses a combination of existing methods, together with information from a range of other sources that indicate a youth's involvement with drugs.

\section{Background: Substance Use in Adolescent Development}

Drug use is implicated in a number of developmental problems in adolescence: poor academic performance (Lynskey and Fergusson, 1995; McCluskey et al., 2002), sexual precocity (Elliott and Morse, 1989), aggression and violence (Brook, Whiteman, and Finch, 1992; Windle, 1990), gang involvement (Fagan, 1989), and mental distress and disorder (Cohen et al., 1990). Drug use is prevalent among American youth: 4.9 million youth between 12 and 17 years of age report using illicit substances in the past year, and more than 1 million of these youth have a substance dependence disorder (U.S. Department of Health and Human Ser vices, 2002). More than half of all 12th grade students report using illicit substances, and about one-quarter report using them in the past 30 days (J ohnston, O'Malley, and Bachman, 2003). In addition, 28.5 percent of all high school students report being offered drugs, selling drugs, or obtaining drugs on school property in the past year (Grunbaum et al., 2002).

Recent advances in the understanding of adolescent development make these figures on substance use even more disturbing. It is now known that deviant careers have distinct patterns. Problem behaviors cluster together in time, and they often follow typical sequences of development over the life span. These patterns are often called pathways. ${ }^{1}$ Although there is no universally accepted categorization of these patterns or pathways, the following generalizations about drug use and adolescent development are generally recognized:

- Substance use commonly follows a sequence from tobacco and alcohol to cannabis and then to more dangerous substances (Newcomb and Bentler,
1990; Rutter, 1996; Yamaguchi and Kandel, 1984a, 1984b).

- Beginning substance use and abuse in early adolescence is associated with:

* More serious delinquency and longer deviant careers (Moffitt, 1993a; Craddock, Collins, and Timrots, 1994; Harrison and Gfroerer, 1992; Brook et al., 1996; Loeber, StouthamerLoeber, and White, 1999).

* Antisocial personality disorders in later life (Myers, Stewart, and Brown, 1998; van den Bree, Svikis, and Pickens, 2000).

* More numerous risk behaviors (Elliott and Morse, 1989; Pedersen and Hegna, 2003; Duncan, Strycker, and Duncan, 1999).

- Substance abuse is associated with poor academic performance (McCluskey et al., 2002).

- More severe substance abuse and dependence are associated with more serious criminal offenses in general (Elliott, Huizinga, and Menard, 1989; Mason and Windle, 2002).

- Substance use and abuse are associated with higher rates of psychiatric disorders and with more severe psychiatric disorders (Elliott, Huizinga, and Menard, 1989; Abram, Teplin, and McClelland, 2003; Brook, Cohen, and Brook, 1998; Deykin and Buka, 1997; Shedler and Block, 1990).

Although substance use is not thought to cause all of these problems, it is empirically associated with a number of problem behaviors and with adolescent delinquency in general. For this reason, the detection of substance use among juveniles in the justice system will help identify youth at greatest risk for serious problems and those most likely to benefit from treatment and diversion.

\section{Measuring Substance Use Among Detainees: Self-Report or Bioassay?}

Self-report and bioassay are the two techniques most commonly used to detect substance use in detained populations. There is great variety within each of these techniques. Self-report information can be obtained by using a mail questionnaire, a self-administered computerized instrument, or a face-to-face interview. Bioassay, or biological measurement, can be done with various tissues and fluids. No gold standard exists for assessment of substance use. Each method has its strengths and weaknesses.

\section{Self-Report}

Self-report is the least expensive, most easily administered method of assessing substance use. For this reason, large national studies rely on self-report data to generate prevalence rates of substance use (Craddock, Collins, and Timrots, 1994; Harrison and Gfroerer, 1992; Golub et al., 2002; U.S. Department of Health and Human Services, 1996). For self-report data to be valid, subjects must understand the questions, accurately recall the information requested, and disclose information honestly (Lessler and O'Reilly, 1997; Turner et al., 1998; Wasserman et al., 2002; Catania et al., 1990; Huang, Watters, and Case, 1988; Miller, 1997). Each of these requirements poses challenges in juvenile justice settings.

Understanding questions. Drugs of abuse have a wide range of street names, and these names vary greatly from setting to setting. Because subjects may be unfamiliar with street names of drugs used in other neighborhoods, social strata, or ethnic groups, interviewers must be trained to be sensitive to each subject's background, demeanor, and linguistic preferences. In addition, because many juvenile justice detainees have limited reading skills, self-administered questionnaires and computerized instruments that are useful in other settings may be problematic for detained youth.

Recalling information. Drug use itself might compromise a subject's ability to recall specifics. However, although impaired recall poses problems for assessing patterns and details of substance use, recall of recent use is unlikely to be so impaired as to prevent identification of youth in need of treatment.

Answering honestly. The greatest barrier to accurate self-reporting of drug use is unwillingness to disclose honestly. Detainees-both adult and juvenile-are understandably reticent about reporting illegal behavior, and self-reported drug use data from these groups, therefore, are likely to lack validity. ${ }^{2}$ 


\section{Bioassay}

At its best, bioassay promises to circumvent the problems of self-reporting. Bioassay, however, does not solve all the problems associated with measuring drug use. Common to any bioassay is the premise that the drug or a metabolic byproduct unique to the body's processing of the drug will be present in the fluids or tissues tested. Two issues confront all bioassay methods: first, what tissue or fluid to test; and second, how to measure the presence of a drug or its metabolite. These two issues frame most of the debate over the validity and usefulness of bioassay.

Choosing tissues or fluids. Bioassays can be done with urine, hair, saliva, sweat, blood, and semen. Most detention facilities use urine or hair, both of which are relatively easy to collect. ${ }^{3}$ In general, urine testing is sensitive only to drugs used within the last 2 or 3 days (Mieczkowski and Newel, 1993; Cone, 1997; Council on Scientific Affairs, 1987; Wolff et al., 1999). ${ }^{4}$ Although hair analysis initially promised to provide a record of drug use for weeks or even months, troublesome issues have yet to be resolved: external contamination may result in false-positive findings, ${ }^{5}$ and cocaine may bind to hair more readily than cannabis or opiates and may bind more readily to some types of hair than others (which may cause racial differences in sensitivity to hair analysis) (Baumgartner, Hill, and Blahd, 1989; Mieczkowski and Newel, 1997; Miller, Donnelly, and Martz, 1997).

Choosing a method of analysis. Many techniques are available for identifying drugs in urine or hair (Visher and McFadden, 1991; Riley, Lu, and Taylor, 2000):

\section{- Gas chromatography/mass spectrom-} etry. GC/MS is the best method for detecting drugs (i.e., the least likely to produce false-negative or false-positive results), but it is also the most costly. GC/MS requires trained technicians, lengthy preparation of samples, and expensive laboratory equipment.

\section{- Other chromatographic methods.} High-performance liquid chromatography (HPLC) performs well but also requires expensive equipment. Thinlayer chromatography (TLC) is inexpensive but not as reliable as other chromatographic methods.

- Immunoassay. The most commonly used immunoassay methods are radioimmunoassay and enzyme-multiplied immunoassay. In both methods, a drugbinding antibody is added to a sample, and the level of antibody activity is then measured. Although these methods are relatively inexpensive and easily executed, they have drawbacks: a different antibody must be developed for each drug tested, and the antibodies sometimes bind to substances that are chemically similar to the drug in question (resulting in false positives, such as mistaking over-the-counter cold remedies for amphetamines).

\section{Previous Studies}

Research has demonstrated not only high levels of substance use among detained youth but also shortcomings of self-report measures in this population. Table 1 summarizes seven studies that used self-reports and/or bioassays to measure drug use in juvenile detainees.

As the table shows, the level of self-reported cannabis and cocaine use varies markedly from study to study. For both drugs, selfreports of use decline sharply when subjects are asked about more recent use. Urinalysis results for cannabis are fairly consistent for three of the four studies; results for cocaine are more consistent across studies. Hair analysis results vary for both drugs. The variation in bioassay results may be attributable to the studies' methodological differences: they sampled youth at different stages of the juvenile justice process, were designed for different purposes, and had different rates of refusal or noncompliance.

Veracity of self-report data could be computed for only a few of the studies. For cannabis, one study found that 60.4 percent of juveniles who tested positive reported use in the past 3 days, and another found that all juveniles who tested positive reported lifetime use and 81.0 percent reported "recent" use. For cocaine, veracity of selfreport data was strikingly poor: of those who tested positive, only 22.7 percent reported use in the past 3 days, 22.1 to 23.4 percent reported use in the past 3 months, and 50.0 percent reported "recent" use. In other words, at least half of recent cocaine users denied use.

Studies of detained adults (Golub et al., 2002; Gray and Wish, 1999; Harrison, 1995; Mieczkowski, 1990) have found self-report veracity levels for cannabis and cocaine that are similar to those found for juveniles. As with juveniles, self-reports of use decline when subjects are asked about more recent use, and veracity levels are markedly lower for cocaine than for cannabis. For adults, the veracity level for opiate use is generally higher than that for cocaine use.

To summarize:

- Both self-report and bioassay data confirm that substantial numbers of juvenile and adult detainees use drugs.

- Self-report veracity is poor among both juveniles and adults, especially when they are asked about recent use.

- Self-report veracity is related to the type of drug. Cannabis use is more likely to be reported than cocaine use, probably because the former is more socially acceptable (Golub et al., 2002; Harrison, 1995; Mieczkowski et al., 1991; Fendrich and $\mathrm{Xu}, 1994)$ and because it carries less severe legal consequences.

Two key questions have not been adequately addressed in the existing literature: First, does the veracity of self-reported drug use differ across demographic groups (i.e., age, gender, and race/ethnicity)? Second, what is the best approach for identifying drug use among juvenile detainees, given the demonstrated shortcomings of the various measures? These questions are addressed below.

\section{Findings From the Northwestern Juvenile Project}

The study reported in this Bulletin uses self-report and urinalysis results from the Northwestern J uvenile Project to compare the veracity of self-reported drug use across demographic groups and to identify the best approach for assessing drug use among juvenile detainees. The study focuses on self-report and urinalysis for three reasons: they are the most widely used, best understood measures of substance use; they can be administered by trained lay personnel (a practical consideration for juvenile justice facilities); and the level of agreement and disagreement between the two measures is relatively well documented.

This section describes the study's sample and methods, presents an overview of findings, and then looks at findings for the two substances most commonly used by juvenile detainees-cannabis and cocaineby subject characteristics (gender, race/ ethnicity, age, prior treatment for substance abuse, and recent drug charges). 
Table 1: Drug Use by Detained Juveniles: Studies of Prevalence and Self-Report Veracity

\begin{tabular}{|c|c|c|c|c|c|}
\hline Study & Design & $\begin{array}{l}\text { Prevalence } \\
\text { Based on } \\
\text { Self-Reports } \\
\end{array}$ & $\begin{array}{l}\text { Prevalence } \\
\text { Based on } \\
\text { Urinalysis } \\
\end{array}$ & $\begin{array}{c}\text { Prevalence } \\
\text { Based on } \\
\text { Hair Analysis }\end{array}$ & $\begin{array}{c}\text { Veracity of } \\
\text { Self-Report } \\
\text { Data* }\end{array}$ \\
\hline $\begin{array}{l}\text { Wislar and } \\
\text { Fendrich, } 2000\end{array}$ & $\begin{array}{l}\mathrm{N}=3,048 \\
\text { juvenile } \\
\text { arrestees and } \\
\text { detainees }\end{array}$ & $\begin{array}{l}\text { Past } 3 \text { days } \\
\text { Cannabis } 31 \% \\
\text { Cocaine } 2.8 \%\end{array}$ & $\begin{array}{l}\text { Cannabis } 31.4 \% \\
\text { Cocaine } 7.3 \%\end{array}$ & $\begin{array}{l}\text { Not } \\
\text { administered }\end{array}$ & $\begin{array}{l}\text { Past } 3 \text { days } \\
\text { Cannabis } 60.4 \% \\
\text { Cocaine } 22.7 \%\end{array}$ \\
\hline $\begin{array}{l}\text { Dembo et al., } \\
1999\end{array}$ & $\begin{array}{l}\mathrm{N}=80 \text { youth } \\
\text { arrested and } \\
\text { completing a } \\
\text { court-ordered } \\
\text { treatment } \\
\text { program }\end{array}$ & $\begin{array}{l}\text { Past } 3 \text { months } \\
\text { Cannabis } 51.3 \% \\
\text { Cocaine } 7.5 \%\end{array}$ & $\begin{array}{l}\text { Not } \\
\text { administered } \\
\text { at baseline }\end{array}$ & $\begin{array}{l}\text { Cannabis } 32.5 \% \\
\text { Cocaine } 18.75 \%\end{array}$ & $\begin{array}{l}\text { Cannot be } \\
\text { computed }^{\dagger}\end{array}$ \\
\hline $\begin{array}{l}\text { Mieczkowski, } \\
\text { Newel, and Wraight, } \\
1998\end{array}$ & $\begin{array}{l}\mathrm{N}=407 \text { juvenile } \\
\text { detainees } \\
\text { interviewed } \\
\text { within } 48 \text { hours } \\
\text { of detention }\end{array}$ & $\begin{array}{l}\text { Past } 3 \text { days } \\
\text { Cannabis } 25.3 \% \\
\text { Cocaine } 0.9 \% \\
\text { Past } 30 \text { days } \\
\text { Cannabis } 50.6 \% \\
\text { Cocaine } 3.2 \% \\
\text { Ever } \\
\text { Cannabis } 85.6 \% \\
\text { Cocaine } 13.2 \%\end{array}$ & $\begin{array}{l}\text { Cannabis } 34.8 \% \\
\text { Cocaine } 7.1 \%\end{array}$ & $\begin{array}{l}\text { Cannabis } 38.5 \% \\
\text { Cocaine } 22.0 \%\end{array}$ & $\begin{array}{l}\text { Cannot be } \\
\text { computed }^{\dagger}\end{array}$ \\
\hline $\begin{array}{l}\text { Magura, Kang, and } \\
\text { Shapiro, } 1995\end{array}$ & $\begin{array}{l}\mathrm{N}=121 \text { youth } \\
\text { followed up after } \\
\text { release from jail }\end{array}$ & $\begin{array}{l}\text { Past } 30 \text { days } \\
\text { Cocaine } 22 \% \\
\text { Past } 3 \text { months } \\
\text { Cocaine } 23 \% \\
\text { Ever } \\
\text { Cocaine } 35 \%\end{array}$ & $\begin{array}{l}\text { Not } \\
\text { administered }\end{array}$ & $\begin{array}{l}\text { Cocaine } \\
51 \%-67 \% \neq\end{array}$ & $\begin{array}{l}\text { Past } 3 \text { months } \\
\text { Cocaine } 22.1 \% \text { - } \\
23.4 \%^{\ddagger}\end{array}$ \\
\hline $\begin{array}{l}\text { Feucht, Stephens, } \\
\text { and Walker, } 1994\end{array}$ & $\begin{array}{l}\mathrm{N}=88 \text { detained } \\
\text { youth }\end{array}$ & $\begin{array}{l}\text { Past month } \\
\text { Cocaine } 3.4 \% \\
\text { Past } 90 \text { days } \\
\text { Cocaine } 5.7 \% \\
\text { Ever } \\
\text { Cocaine } 7.4 \%\end{array}$ & Cocaine $7.8 \%$ & Cocaine $56.8 \%$ & $\begin{array}{l}\text { Cannot be } \\
\text { computed }^{\dagger}\end{array}$ \\
\hline $\begin{array}{l}\text { Dembo et al., } \\
1993\end{array}$ & $\begin{array}{l}\mathrm{N}=399 \text { detained } \\
\text { youth }\end{array}$ & $\begin{array}{l}\text { Authors do not } \\
\text { provide self- } \\
\text { report data }\end{array}$ & $\begin{array}{l}\text { Cannabis } 34.3 \% \\
\text { Cocaine } 9 \% \\
\text { Opiates } 0.5 \%\end{array}$ & $\begin{array}{l}\text { Not } \\
\text { administered }\end{array}$ & $\begin{array}{l}\text { Cannot be } \\
\text { computed }^{\dagger}\end{array}$ \\
\hline $\begin{array}{l}\text { Dembo et al., } \\
1987\end{array}$ & $\begin{array}{l}\mathrm{N}=66 \text { juveniles } \\
\text { ordered into } \\
\text { secure detention } \\
\text { ( } 6 \text { refused urine } \\
\text { test) }\end{array}$ & $\begin{array}{l}\text { Authors do not } \\
\text { provide self- } \\
\text { report data }\end{array}$ & $\begin{array}{l}\text { Cannabis } 53 \% \\
\text { Cocaine } 6.1 \% \\
\text { Barbiturates } 4.6 \%\end{array}$ & $\begin{array}{l}\text { Not } \\
\text { administered }\end{array}$ & $\begin{array}{l}\text { Recent }^{\S} \\
\text { Cannabis } 81 \% \\
\text { Cocaine } 50 \% \\
\text { Lifetime } \\
\text { Cannabis } 100 \%\end{array}$ \\
\hline
\end{tabular}

* Among youth who tested positive, the percentage who reported use.

† Veracity cannot be computed for several studies because self-report data are not provided specifically for positive urinalysis or hair analysis test results.

‡ The ranges reflect the authors' two cutoff levels for establishing cocaine content in hair: $>2 \mathrm{ng} / 10 \mathrm{mg}$ and $>5 \mathrm{ng} / 10 \mathrm{mg}$. The latter, more conservative figure is the conventional cutoff level.

$\S$ The authors do not define recency of use. 


\section{Sample and Methods}

Sample. The Northwestern Juvenile Project is an ongoing longitudinal study of high-risk youth sampled from the Cook County Juvenile Temporary Detention Center (CCJTDC) in Chicago, IL. CCJTDC was selected for study because of its urban location (most juvenile detainees nationwide are in urban areas) and because Cook County is ethnically diverse and has a large Hispanic population (Hispanics are the largest minority group in the United States and are overrepresented in the juvenile justice system). In addition, CCJTDC's size (approximately 8,500 admissions each year, daily census of 650 , and daily intake of 20) ensured adequate numbers of subjects for key subgroups such as females and Hispanics.

The CCJTDC sample was stratified by gender, race/ethnicity (African American, nonHispanic white, Hispanic), age (10-13 or 14 and older), and legal status (processed as a juvenile or as an adult). All estimates reported in this Bulletin were weighted to reflect the CCJTDC sample (Little and Schenker, 1995; Cochran, 1977).

Initial sampling and baseline interviews were conducted between November 1995 and J une 1998. The final sample size for the project was 1,829 . Additional information on the sample and study design is available elsewhere (Teplin et al., 2002; Abram et al., 2003; Teplin et al., 2003).

\section{Interviews and urine samples. Trained} interviewers used the Diagnostic Interview Schedule for Children (DISC 2.3) to gather information on substance use. Subjects were assured that the information they revealed would remain confidential and would have no bearing on their legal proceedings. Interviewers built rapport with subjects during the questions that preceded the substance use items (basic demographic information, education, life circumstances, and DISC mental health items). Female subjects were assigned female interviewers, and Spanish-speaking subjects were assigned bilingual interviewers.

The DISC instrument measures use of alcohol, cannabis/hashish, uppers/speed, downers (e.g., barbiturates), tranquilizers (e.g., Valium, Librium, and Ativan), heroin and opiates (including morphine, methadone, and codeine), cocaine/crack cocaine, hallucinogens (including LSD and PCP), and inhalants (e.g., glue). The instrument asks about lifetime use, age at first use, frequency of use in the past year, any use in the past 6 months, and treatment. Because it is designed to assess patterns of use, it does not ask about use in the past 2 or 3 days.

Of the 1,829 subjects interviewed, 1,745 (about 95 percent) provided urine samples. ${ }^{6}$ Some subjects were unwilling or unable to provide samples, and some samples were unavailable for administrative reasons. ${ }^{7}$ The final sample size for the analyses reported in this Bulletin is 1,742 ( 3 subjects did not complete the DISC portion of the interview). ${ }^{8}$

Urinalysis. Enzyme-Multiplied Immunoassay Tests (EMIT) were used to identify illicit drug use by the subjects. The EMIT-10 panel tests for the presence of amphetamines, barbiturates, benzodiazepines (diazepam, nordiazepam, oxazepam, chlordiazepoxide, and norflurazepam), cannabis, cocaine (benzoylecgonine is a cocaine metabolite found in the urine), methaqualone (Quaaludes), opiates (including codeine and morphine), PCP, and propoxyphene (Darvon). Some EMIT-10 panel categories are not exact matches for self-report categories. ${ }^{9}$
Drug charges. Data on recent drug charges (e.g., possession or sale of controlled substances) against subjects were collected from the Cook County Court Clerk's computer system. The period of coverage for these data was from 90 days prior to intake at CCJTDC to 30 days after intake (to account for lagtime between arrests and charges).

\section{Overview of Findings}

Table 2 presents an overview of findingsself-reported use, urinalysis results, and computations of veracity, prevalence, and bias (see "Definitions" sidebar, below)among the total sample of all detained juveniles.

Self-reported use. Self-reported use of any substance was quite common. Use in the past 6 months was reported by 77.3 percent of youth, lifetime use by 90.1 percent. The figures for cannabis were about the same (77.1 percent and 90.1 percent, respectively), an indication that almost all youth who report any substance use report cannabis use. Self-reported use of substances other than cannabis was much less common: 8.0 percent and 13.0 percent

\section{Definitions}

The measures reported in tables $2-4$ and analyzed in the accompanying text are defined below.

Self-reported use: percentage of detained youth who reported substance use.

Urinalysis results: percentage of detained youth who tested positive for substances in EMIT-10 urinalysis.

Veracity: percentage of detained youth who tested positive by urinalysis who also reported use.

Minimum prevalence: estimated prevalence of substance use among detained youth, based on combined self-report and urinalysis results.

Minimum bias for self-report: estimated percentage of detained youth who use drugs and would go undetected if self-report is used without urinalysis (calculated as the difference between minimum prevalence and self-reported use).

Minimum bias for urinalysis: estimated percentage of detained youth who use drugs and would go undetected if urinalysis is used without self-report (calculated as the difference between minimum prevalence and urinalysis results).

Self-reported use and the related measures of veracity, prevalence, and bias are presented separately for use in the past 6 months and ever (lifetime). Prevalence and bias estimates are "minimum" because both self-report and urinalysis measures are expected to underestimate true rates of substance use. 
Table 2: Drug Use by Detained Juveniles in Cook County, IL: Overview of Findings (\%)

\begin{tabular}{|c|c|c|c|c|c|c|c|c|c|c|c|}
\hline \multirow[b]{2}{*}{ Drug } & \multicolumn{2}{|c|}{$\begin{array}{l}\text { Self-Reported } \\
\text { Substance Use }\end{array}$} & \multirow{2}{*}{$\begin{array}{c}\text { Substance } \\
\text { Detected } \\
\text { by } \\
\text { Urinalysis }\end{array}$} & \multicolumn{2}{|c|}{ Veracity } & \multicolumn{2}{|c|}{$\begin{array}{c}\text { Minimum } \\
\text { Prevalence }\end{array}$} & \multicolumn{2}{|c|}{$\begin{array}{l}\text { Minimum } \\
\text { Bias for } \\
\text { Self-Reporting } \\
\end{array}$} & \multicolumn{2}{|c|}{$\begin{array}{l}\text { Minimum } \\
\text { Bias for } \\
\text { Urinalysis }\end{array}$} \\
\hline & 6-Month & Lifetime & & 6-Month & Lifetime & 6-Month & Lifetime & 6-Month & Lifetime & 6-Month & Lifetime \\
\hline Any substance & 77.3 & 90.1 & 66.4 & 87.7 & 94.1 & 85.4 & 94.0 & 8.2 & 3.9 & 19.0 & 27.6 \\
\hline Cannabis & 77.1 & 90.1 & 65.9 & 87.6 & 94.1 & 85.3 & 94.0 & 8.2 & 3.9 & 19.4 & 28.1 \\
\hline Other than cannabis & 8.0 & 13.0 & 5.8 & 27.5 & 37.8 & 12.2 & 16.6 & 4.2 & 3.6 & 6.4 & 10.9 \\
\hline Cocaine & 4.4 & 6.2 & 4.8 & 21.7 & 28.1 & 8.1 & 9.6 & 3.6 & 3.4 & 3.4 & 4.8 \\
\hline Opiates & 1.2 & 2.6 & 0.2 & 65.7 & 65.7 & 1.3 & 2.6 & 0.1 & 0.1 & 1.1 & 2.5 \\
\hline Uppers & 0.8 & 1.8 & 0.0 & $*$ & $*$ & 0.8 & 1.8 & $\dagger$ & $t$ & $\dagger$ & $t$ \\
\hline Downers & 0.3 & 0.5 & 0.0 & $*$ & $*$ & 0.3 & 0.5 & $\dagger$ & $\dagger$ & $\dagger$ & $\dagger$ \\
\hline Tranquilizers & 0.3 & 0.6 & 0.0 & $*$ & $*$ & 0.3 & 0.6 & $\dagger$ & $\dagger$ & $\dagger$ & $\dagger$ \\
\hline Hallucinogens & 5.5 & 9.4 & 1.1 & 33.3 & 39.3 & 6.1 & 10.1 & $\ddagger$ & $\neq$ & $\ddagger$ & $\neq$ \\
\hline
\end{tabular}

Note: $N=1,742$. For explanations of veracity, minimum prevalence, and minimum bias, see "Definitions" sidebar on page 5 .

* Veracity cannot be computed because the EMIT urinalysis result is zero.

† Bias figures are not presented because self-reported use is very limited and bias computations would not, therefore, be meaningful.

₹ Bias figures are not presented because the EMIT urinalysis panel detects PCP but not the other hallucinogens in the DISC self-report instrument and bias computations would, therefore, be misleading.

(6-month and lifetime, respectively) for any other substance, 5.5 percent and 9.4 percent for hallucinogens, 4.4 percent and 6.2 percent for cocaine, and even less for the other categories measured (opiates, uppers, downers, and tranquilizers).

Urinalysis results. In many ways, patterns of use detected by EMIT-10 urinalysis were similar to patterns of self-reported use. However, use rates based on urinalysis results generally were lower than those based on self-reports of 6-month and lifetime use. This is not surprising, given that in urinalysis, the window of sensitivity to drugs generally is only $2-3$ days. Twothirds (66.4 percent) of detainees tested positive for any drug, 65.9 percent for cannabis, 5.8 percent for any substance other than cannabis, 4.8 percent for cocaine, and 1.1 percent for hallucinogens.

Veracity. Overall, self-reporting had a surprisingly high level of veracity. Among all detainees with positive urinalysis results, 87.7 percent reported use of any substance in the past 6 months and 94.1 percent reported lifetime use of any substance. However, although the veracity figures for cannabis ( 87.6 percent for 6 months and 94.1 percent for lifetime) were nearly identical to the overall figures, those for any drug other than cannabis were much lower (27.5 percent and 37.8 percent). This means that cannabis alone was responsible for the high level of veracity in selfreporting of overall drug use. More than three in five detainees who tested positive for use of illicit substances other than cannabis did not accurately report their use.

Minimum prevalence. Based on a combination of self-report and urinalysis results, the minimum prevalence estimates show that at least 85.4 percent of detained youth had used some kind of illicit substance in the past 6 months and at least 94 percent had used an illicit substance at some point in their lifetime. For substances other than cannabis, however, minimum prevalence was much lower: 12.2 percent for 6 months and 16.6 percent for lifetime.

Minimum bias for self-report. This measure, which is the difference between the minimum prevalence estimate and the self-report estimate, indicates that selfreporting without urinalysis overlooked at least 8.2 percent of detained youth who had used some kind of illicit substance in the past 6 months, or almost 1 in 10 youth in detention. This bias drops to 3.9 percent for lifetime use. For substances other than cannabis, self-reporting without urinalysis overlooked 4.2 percent of youth who had used a substance in the past 6 months and 3.6 percent of those with lifetime use. These values were low because overall use of these substances was low. Nevertheless, as the bias and prevalence figures show, self-reporting overlooked one-fourth $(3.6 / 16.6)$ to one-third $(4.2 / 12.2)$ of juveniles who had used substances other than cannabis.

For cocaine specifically, 6-month selfreporting overlooked 3.6 percent of detainees and lifetime self-reporting overlooked 3.4 percent of detainees. The 6 month minimum prevalence for cocaine use was only 8.1 percent, so overlooking 3.6 percent means missing more than one-third of confirmed cocaine users.

For uppers, downers, and tranquilizers, self-reported use was less than 2 percent and EMIT urinalysis findings were zero. Therefore, veracity could not be computed for these substances, and table 2 does not present self-report bias figures for them.

Because very few detainees tested positive for hallucinogens, very few users of hallucinogens would be missed by selfreporting alone. As noted in endnote 9, the EMIT panel detects PCP but not the other hallucinogens in the DISC questionnaire. Therefore, the minimum prevalence estimates for hallucinogens (6.1 percent and 10.1 percent for 6-month and lifetime use, respectively) are biased downward relative to estimates for the other categories of substances. For these reasons, 


\section{Age at Onset of Substance Use}

Juvenile detainees who reported using drugs were asked about age at first use. Their response is disturbing. Ten percent of the youth who reported using drugs said they first used them at or before age 11, and 25 percent reported first use at or before age 12 . Ten percent of youth who reported using cocaine said they first used it before age 11 , and 50 percent reported first use before age 15 .

table 2 does not present self-report bias figures for hallucinogens.

Minimum bias for urinalysis. Minimum biases were greater for urinalysis than for self-reporting, in part because urinalysis has a limited window of sensitivity to drugs. When not combined with selfreporting, urinalysis overlooked one in five detained youth (19.0 percent) who reported using any substance in the past 6 months and one in four (27.6 percent) who reported lifetime use. For substances other than cannabis, urinalysis overlooked 6.4 percent of self-reported 6-month users and 10.9 percent of lifetime users. Table 2 does not present urinalysis bias figures for uppers, downers, tranquilizers, and hallucinogens for the same reasons it does not present self-report bias figures for these substances (see above). (The urinalysis bias for hallucinogens was quite large, but this is probably because of the limited scope of the EMIT test for hallucinogens.)

\section{Analysis: Cannabis}

This section analyzes findings for cannabis. See table 3 and "Definitions" sidebar (page 5).

\section{Gender}

- Although self-reported use of cannabis was about the same for boys and girls (around 75 percent for 6-month use and 90 percent for lifetime use), urinalysis results differed dramatically: 67.4 percent for boys and 45.5 percent for girls. This suggests either that cannabis use was less common among girls than boys or that the temporal association between using cannabis and being arrested was stronger for boys than for girls.
- Veracity in reporting cannabis use was about the same for boys and girls, i.e., most detainees with positive urinalysis results also reported use. However, because boys had a higher rate of positive urinalysis results, their 6-month self-report bias (8.4 percent) was greater than that for girls (5.2 percent). In other words, cannabis use during the past 6 months was more likely to go undetected among boys than among girls if self-reporting was used without urinalysis. Lifetime self-report bias was similar for boys (3.9 percent) and girls (3.3 percent).

- Urinalysis biases were much higher for girls (34.9 percent for 6 months and 46.4 percent for lifetime) than for boys (18.2 percent 6 months, 26.7 percent lifetime), which means that cannabis use would be much more likely to go undetected among girls than among boys if urinalysis testing is used without self-reporting. This again suggests that recent cannabis use was less common among girls than among boys.

\section{Race/ethnicity}

- Among males, self-reported cannabis use was roughly equal for all three racial/ethnic groups.

- Boys in all three racial/ethnic groups had reasonably good veracity for reporting cannabis use, although 6month veracity was slightly lower for African American boys (86.8 percent) than for other boys ( 94.6 percent for non-Hispanic whites and 91.1 percent for Hispanics). Because the rate of positive urinalysis results was higher for African American boys than other boys, the 6-month self-report bias was greater for African Americans (9.2 percent) than for others (3.2 percent for non-Hispanic whites and 5.2 percent for Hispanics).

- Among boys, urinalysis bias for detecting cannabis use was lower for African Americans (24.4 percent for lifetime use) than for other groups (33.6 percent for non-Hispanic whites and 34.3 for Hispanics). The proportion of lifetime cannabis users who would be overlooked when urinalysis is used without self-report methods is smaller for African Americans than for other racial/ethnic groups.

- Unlike males, female detainees in the three racial/ethnic groups differed substantially in their rates of self-reported cannabis use. Only 71.6 percent of African American girls reported use in the past 6 months, compared with 85.4 percent of non-Hispanic whites and 81.2 percent of Hispanics. Lifetime selfreport rates also were lower for African American girls than for other girls.

- Because of the differences in selfreported use, the 6-month self-report bias for cannabis was greater for African American girls ( 6 percent) than for other girls (3.7 percent for non-Hispanic whites and 3.3 percent for Hispanics). The 6-month urinalysis bias was greater for non-Hispanic white girls (41.6 percent) than for African American girls (31.5 percent) and Hispanic girls (37.9 percent). In short, self-reporting alone was most likely to overlook cannabis use among African American girls, whereas urinalysis alone was most likely to overlook its use among non-Hispanic white girls. This finding suggests that among girls, African Americans' self-reports of cannabis use are the least reliable.

\section{Age}

- Among both boys and girls, self-reported cannabis use was less common for detainees ages 10-13 than for older detainees. Among detainees ages 10-13, use in the past 6 months was reported by 56.7 percent of boys and 50.8 percent of girls (compared with 77.3 percent of all boys and 75.1 percent of all girls).

- Among boys, biases for both self-report and urinalysis varied greatly by age: compared with older boys, those ages 10-13 had greater biases (i.e., their cannabis use was more likely to go undetected when either detection method was used alone). In contrast, biases among girls did not vary greatly by age.

\section{Prior treatment for substance abuse}

- Almost all boys and girls who reported prior treatment for substance use had very substantial self-reported cannabis use and consequently had very low self-report bias.

- Urinalysis detection for cannabis was much more common for boys who reported prior treatment (87.9 percent) than for girls who reported prior treatment ( 57.4 percent). Because so many boys who reported prior treatment tested positive, their urinalysis bias (11.9 percent for lifetime use) was 
much smaller than that for girls who reported prior treatment (42.6 percent for lifetime use).

\section{Recent arrests for drug offenses}

- Self-reported cannabis use and positive urinalysis results for cannabis were more common among detainees with recent drug arrests than among those with no recent drug arrests.

- Detainees with recent drug arrests were quite forthcoming about their cannabis use: veracity for self-reported use in the past 6 months was well above 80 percent for both males and females, and lifetime veracity was above 90 percent.

- For both 6-month and lifetime use, minimum prevalence exceeded 90 percent for male and female detainees with recent drug arrests.

\section{Analysis: Cocaine}

This section analyzes findings for cocaine. See table 4 and "Definitions" sidebar (page 5).

\section{Gender}

- Rates of self-reported cocaine use among detainees were more than twice as high for girls as for boys: 9.6 percent versus 4 percent for 6-month use and 12.4 percent versus 5.7 percent for lifetime use.

- In contrast, rates of positive urinalysis results for cocaine were slightly lower for girls (3.7 percent) than for boys ( 4.9 percent). As discussed above (page 3 ), other studies have found that veracity in reporting cocaine use is generally

Table 3: Drug Use by Detained Juveniles in Cook County, IL: Analysis of Findings for Cannabis (\%)

\begin{tabular}{|c|c|c|c|c|c|c|c|c|c|c|c|c|}
\hline & \multicolumn{2}{|c|}{$\begin{array}{l}\text { Self-Reported } \\
\text { Substance Use }\end{array}$} & \multirow{2}{*}{$\begin{array}{c}\text { Substance } \\
\text { Detected } \\
\text { by } \\
\text { Urinalysis }\end{array}$} & \multicolumn{2}{|c|}{ Veracity } & \multicolumn{2}{|c|}{$\begin{array}{l}\text { Minimum } \\
\text { Prevalence }\end{array}$} & \multicolumn{2}{|c|}{$\begin{array}{l}\text { Minimum } \\
\text { Bias for } \\
\text { Self-Reporting }\end{array}$} & \multicolumn{2}{|c|}{$\begin{array}{l}\text { Minimum } \\
\text { Bias for } \\
\text { Urinalysis }\end{array}$} & \multirow[b]{2}{*}{ e N } \\
\hline & 6-Month & Lifetime & & 6-Month & Lifetime & 6-Month & Lifetime & 6-Month & Lifetime & 6-Month & Lifetime & \\
\hline $\begin{array}{l}\text { MALE } \\
\text { Race }\end{array}$ & 77.3 & 90.2 & 67.4 & 87.6 & 94.2 & 85.7 & 94.1 & 8.4 & 3.9 & 18.2 & 26.7 & 1,126 \\
\hline African American & 77.1 & 89.9 & 69.9 & 86.8 & 93.7 & 86.3 & 94.3 & 9.2 & 4.4 & 16.4 & 24.4 & 552 \\
\hline Non-Hispanic white & 81.0 & 91.7 & 59.5 & 94.6 & 97.8 & 84.2 & 93.0 & 3.2 & 1.3 & 24.4 & 33.6 & 199 \\
\hline Hispanic & 78.1 & 91.6 & 58.9 & 91.1 & 97.3 & 83.3 & 93.2 & 5.2 & 1.6 & 24.4 & 34.3 & 372 \\
\hline \multicolumn{13}{|l|}{ Age } \\
\hline $10-13$ & 56.7 & 70.3 & 46.6 & 70.5 & 81.4 & 70.5 & 79.0 & 13.8 & 8.7 & 23.9 & 32.3 & 306 \\
\hline $14-15$ & 75.5 & 88.2 & 69.0 & 85.0 & 90.6 & 85.9 & 94.6 & 10.4 & 6.5 & 16.9 & 25.7 & 344 \\
\hline $16+$ & 82.5 & 95.6 & 70.0 & 91.8 & 98.7 & 88.3 & 96.5 & 5.7 & 0.9 & 18.2 & 26.5 & 476 \\
\hline \multicolumn{13}{|l|}{ Prior treatment } \\
\hline & 95.6 & 98.2 & 74.8 & 97.5 & 99.0 & 97.4 & 99.0 & 1.8 & 0.7 & 22.6 & 24.2 & 616 \\
\hline Yes & 99.3 & 99.7 & 87.9 & 100.0 & 100.0 & 99.3 & 99.7 & 0.0 & 0.0 & 11.4 & 11.9 & 158 \\
\hline \multicolumn{13}{|l|}{ Recent drug charges } \\
\hline None & 74.7 & 88.5 & 60.6 & 88.2 & 95.0 & 81.8 & 91.5 & 7.1 & 3.0 & 21.2 & 30.9 & 857 \\
\hline Any & 82.4 & 93.6 & 81.2 & 86.5 & 93.0 & 93.4 & 99.3 & 10.9 & 5.7 & 12.1 & 18.1 & 269 \\
\hline $2+$ & 84.9 & 97.7 & 77.5 & 89.8 & 98.8 & 92.8 & 98.6 & 7.9 & 0.9 & 15.3 & 21.1 & 87 \\
\hline $\begin{array}{l}\text { FEMALE } \\
\text { Race }\end{array}$ & 75.1 & 88.5 & 45.5 & 88.6 & 92.7 & 80.3 & 91.8 & 5.2 & 3.3 & 34.9 & 46.4 & 616 \\
\hline African American & 71.6 & 86.1 & 46.1 & 87.1 & 90.8 & 77.6 & 90.3 & 6.0 & 4.2 & 31.5 & 44.2 & 404 \\
\hline Non-Hispanic white & 85.4 & 96.3 & 47.5 & 92.3 & 97.4 & 89.0 & 97.6 & 3.7 & 1.2 & 41.6 & 50.1 & 81 \\
\hline Hispanic & 81.2 & 93.1 & 46.6 & 93.0 & 97.8 & 84.5 & 94.1 & 3.3 & 1.0 & 37.9 & 47.5 & 130 \\
\hline \multicolumn{13}{|l|}{ Age } \\
\hline $10-13$ & 50.8 & 68.3 & 22.4 & 71.1 & 71.1 & 57.3 & 74.8 & 6.5 & 6.5 & 34.9 & 52.4 & 50 \\
\hline $14-15$ & 76.5 & 89.1 & 44.8 & 90.4 & 93.6 & 80.8 & 92.0 & 4.3 & 2.9 & 36.0 & 47.1 & 334 \\
\hline $16+$ & 78.4 & 92.1 & 51.2 & 88.1 & 93.7 & 84.5 & 95.3 & 6.1 & 3.3 & 33.3 & 44.1 & 232 \\
\hline \multicolumn{13}{|l|}{ Prior treatment } \\
\hline No & 94.4 & 98.5 & 55.5 & 98.9 & 99.4 & 95.0 & 98.8 & 0.6 & 0.3 & 39.4 & 43.3 & 311 \\
\hline Yes & 97.8 & 100.0 & 57.4 & 97.8 & 100.0 & 99.1 & 100.0 & 1.3 & 0.0 & 41.7 & 42.6 & 94 \\
\hline \multicolumn{13}{|l|}{ Recent drug charg } \\
\hline None & 74.2 & 88.0 & 42.6 & 89.4 & 93.1 & 78.7 & 91.0 & 4.5 & 2.9 & 36.1 & 48.4 & 547 \\
\hline Any & 82.6 & 92.4 & 67.2 & 84.7 & 90.9 & 92.8 & 98.5 & 10.2 & 6.1 & 25.7 & 31.3 & 69 \\
\hline $2+$ & 86.7 & 92.2 & 67.9 & 88.5 & 88.5 & 94.5 & 100.0 & 7.8 & 7.8 & 26.6 & 32.1 & 14 \\
\hline
\end{tabular}

Note: For explanations of veracity, minimum prevalence, and minimum bias, see "Definitions" sidebar on page 5. 
poor among both juvenile and adult detainees. In the current study, veracity for cocaine was much lower among boys than among girls, for both 6-month use (20.8 percent for boys, 36.2 percent for girls) and lifetime use (27.4 percent for boys, 39.4 percent for girls).

- Combining self-report and urinalysis results, minimum prevalence rates were higher for girls ( 12 percent for 6-month use, 14.6 percent for lifetime use) than for boys (7.8 percent 6-month, 9.2 percent lifetime). Self-report bias was greater for boys than for girls (3.7 percent versus 2.4 percent, respectively, for 6-month reports).

\section{Race/ethnicity}

- African American boys and girls reported almost no cocaine use-less than 1 percent for boys, and less than 2 percent for girls, for both 6-month and lifetime use. In addition, their urinalysis detection rates for cocaine were less than half the rates for other boys and girls. Urinalysis detection of cocaine was most common among Hispanic boys.

- Veracity in reporting cocaine use was good among non-Hispanic whites, especially among girls: 61.5 percent (6-month) and 78.6 percent (lifetime) for boys,

Table 4: Drug Use by Detained Juveniles in Cook County, IL: Analysis of Findings for Cocaine (\%)

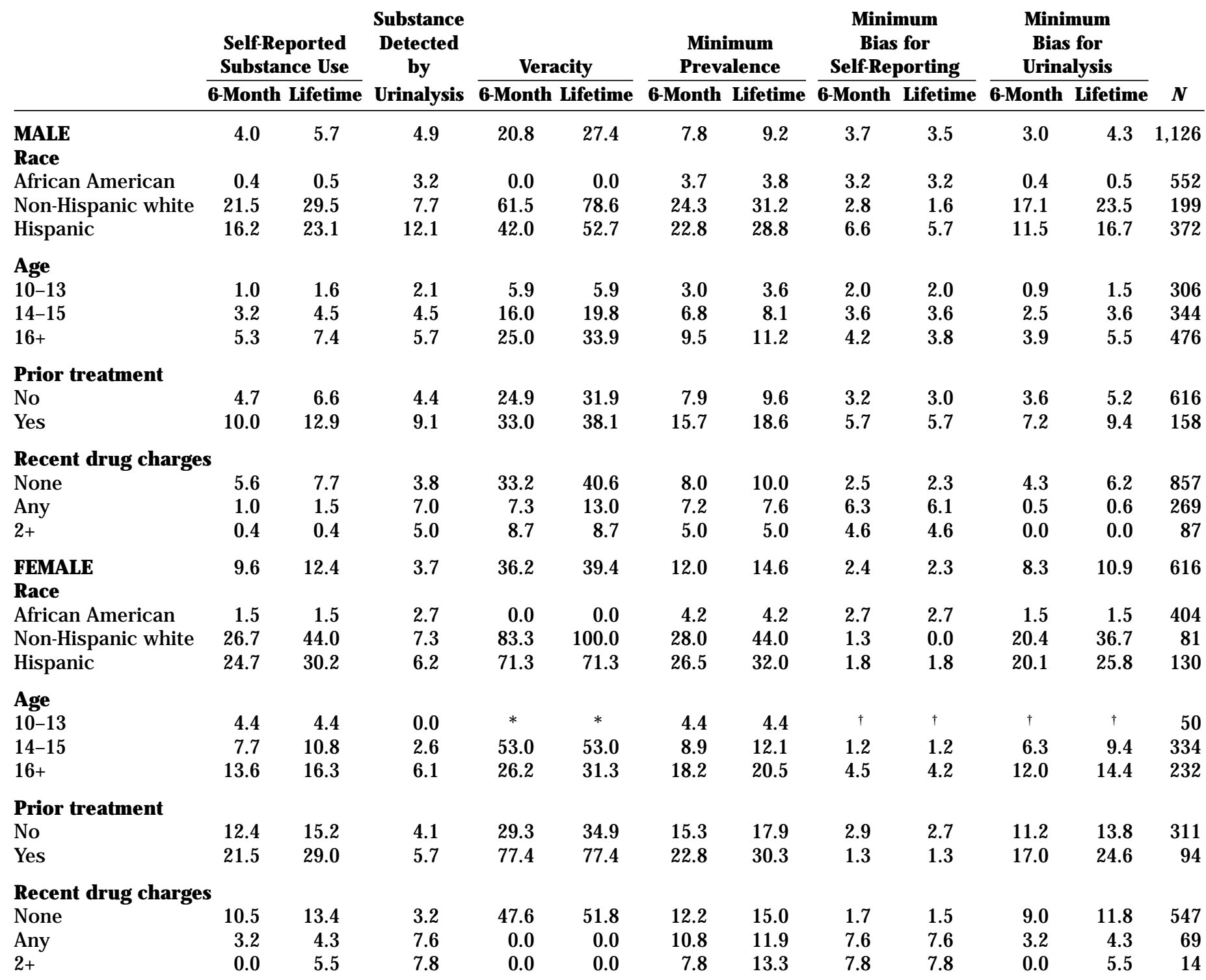

Note: For explanations of veracity, minimum prevalence, and minimum bias, see "Definitions" sidebar on page 5.

* Veracity cannot be computed because the EMIT urinalysis result is zero.

$\dagger$ Bias figures are not presented because self-reported use is very limited and bias computations would not, therefore, be meaningful. 
83.3 percent (6-month) and 100 percent (lifetime) for girls.

- In contrast, veracity for cocaine use among African American boys and girls was zero, for both 6-month and lifetime use. Among Hispanic boys, veracity was 42 percent (6-month) and 52.7 percent (lifetime); among Hispanic girls, veracity was 71.3 percent for both 6-month and lifetime reports.

- Among boys, the minimum prevalence for cocaine use was less than 4 percent for African Americans, compared with more than 20 percent for non-Hispanic whites and Hispanics, for both 6-month and lifetime use.

- For both 6-month and lifetime use, the minimum prevalence for cocaine use was slightly more than 4 percent for African American girls and exceeded 25 percent for non-Hispanic white girls and for Hispanic girls. Minimum prevalence was greatest for lifetime use by non-Hispanic white girls.

\section{Age}

- Among boys, all of the cocaine measures increased with age, including rates of self-reported use, positive urinalysis results, veracity, minimum prevalence, and biases for self-reporting and urinalysis.

- Because urinalysis results for cocaine were zero for girls ages 10-13, veracity and bias results are not presented for this group. Among girls ages 14 and older, all of the cocaine measures except veracity increased with age. For girls ages $14-15$, the veracity rate for reporting cocaine use was 53.0 percent (for both 6-month and lifetime use), compared with 26.2 percent (6-month) and 31.3 percent (lifetime) for girls ages 16 and older.

\section{Prior treatment for substance abuse}

- Among both boys and girls, self-report rates for cocaine use among detainees who reported prior treatment for substance abuse were about twice as high as the rates for detainees who did not report prior treatment. Rates were higher for girls with prior treatment than for boys with prior treatment.

- Veracity for reporting cocaine use was good among girls with prior treatment (77.4 percent for both 6-month and lifetime use); veracity was much lower among boys with prior treatment ( 33 percent for 6-month use and 38.1 percent for lifetime use).

\section{Recent arrests for drug offenses}

- Among both boys and girls, rates of selfreported cocaine use were lower and rates of positive urinalysis results for cocaine were higher among detainees with recent drug arrests than among those with no recent drug arrests.

- Veracity for self-reported cocaine use was much poorer among detainees with recent drug arrests than among those with no recent drug arrests. Among boys, veracity was more than 30 percent for detainees with no recent drug arrests but only 7.3 percent (6-month use) and 13 percent (lifetime use) for those with a drug arrest. Among girls, veracity was about 50 percent for detainees with no recent drug arrests but zero for those with a drug arrest.

\section{Implications}

What are the implications of the current study's findings? The most important finding is the general confirmation of high rates of drug use among youth entering detention. Virtually all (94 percent) of the youth entering detention had used drugs during their lifetime, and 85.4 percent had used drugs in the past 6 months. Twothirds (66.4 percent) of detainees tested positive for drugs in urinalysis. Probably because cannabis use is commonplace among these youth, their veracity in reporting its use was generally good. The low self-report and urinalysis biases for cannabis are an indication that few juveniles who use it will be overlooked by either approach to detection. Because cannabis use often leads to more serious drug use (Kandel and Yamaguchi, 1993; Yamaguchi and Kandel, 1984a, 1984b), almost all youth entering detention can be considered at risk for developing substance use problems.

Identifying youth in acute need of treatment is much more difficult. For example, detecting use of substances other than cannabis is far more problematic than detecting cannabis use. Although the minimum prevalence estimates indicate that only one in eight detainees had used a substance other than cannabis, neither self-reporting nor urinalysis appears to provide an acceptable measure of such use. As can be seen in table 2, self-reports alone overlooked at least one-third of detainees who used substances other than cannabis in the past 6 months (4.2/ 12.2 [minimum bias for self-reporting/ minimum prevalence] $=34.4$ percent), and urinalysis alone overlooked at least half of these detainees $(6.4 / 12.2$ [ minimum bias for urinalysis/minimum prevalence $]=52.5$ percent).

In addition, certain groups of detainees require special attention. For example, in this study, younger detainees, African American detainees, and detainees with recent drug arrests in particular lacked veracity in self-reporting drug use. Females had lower rates of detection by urinalysis, although further research is needed to understand exactly why. Detainees with histories of substance abuse treatment require special attention because of their higher rates of substance use and their histories of drug abuse.

In short, among youth who have made the transition to using drugs more serious than marijuana, neither self-reporting nor urinalysis provides a good measure of use. Most detained youth who test positive by urinalysis for substances other than cannabis do not reply honestly to questions about their drug use. Furthermore, use of these substances is likely to go undetected in urinalysis because the test has such a limited window of sensitivity to drugs.

The practical lesson is that self-reporting and urinalysis should be used in combination with each other and in conjunction with other resources, such as histories of treatment for substance abuse, records of drug-related arrests and charges, and information from families and schools on youth's drug use. All avenues should be explored in efforts to identify those youth in greatest need of intervention.

\section{Endnotes}

1. The concept of patterns or pathways of problem behavior is widely discussed in the literature (Newcomb and Bentler, 1990; Cohen et al., 1990; Elliott, Huizinga, and Menard, 1989; Kandel and Yamaguchi, 1993; Kandel and Logan, 1984; Loeber and Hay, 1997; Loeber et al., 1991, 1993; Moffitt, 1993a, 1993b; Rutter, 1996; Yamaguchi and Kandel, 1984a, 1984b).

2. A large body of research has questioned the validity of self-reported drug use data from adult arrestees (Golub et al., 2002; Dej ong and Wish, 2000; Gray and Wish, 
1999; Harrison, 1995; Mieczkowski, 1990; Mieczkowski et al., 1991; Mieczkowski and Newel, 1993) and detained juveniles (Dembo et al., 1987, 1993, 1999; Feucht, Stephens, and Walker, 1994; Magura, Kang, and Shapiro, 1995; Mieczkowski, Newel, and Wraight, 1998; Wislar and Fendrich, 2000).

3. Saliva analysis has problems of contamination and different absorption rates for different drugs. Sweat collection is impractical in many settings because the subject must be available for 24 to 48 hours. Collection of blood requires a licensed health care professional. Semen presents obvious collection problems and is, of course, gender specific. Both urine and hair can be collected by trained lay personnel. Urine has additional advantages: many substances are concentrated in the urine by normal kidney functions, and, compared with other fluids, urine is relatively free of cellular components that can interfere with drug testing. The collection of any fluid or tissue, including urine and hair, poses special problems for juvenile justice settings: because subjects are detained, they may feel coerced and are more likely to be noncompliant. In fact, collection for forensic purposes may require a court order.

4. However, the detection period for urinalysis can be as long as 3 weeks for heavy use of cannabis and as long as 30 days for use of phencyclidine (PCP), benzodiazepines, and some long-acting barbiturates.

5. How drugs become part of the hair follicle is not clear. They may pass from the blood to the follicle as it is formed, or they may be transferred to the follicle from sweat and sebum (in which case environmental exposure rather than actual drug use could result in a positive finding).

6. The mean time between intake and sampling was 1.5 days. The median time was 1 day.

7. Fourteen subjects refused to provide a sample, 17 were unable to urinate, 7 samples were too small to analyze, and 8 were not collected because too much time had elapsed since intake. Thirty-eight samples were missing because procedures were not yet in place or equipment and supplies were unavailable.

8. Some subjects who were included in the analysis did not complete certain portions of the DISC interview. One subject refused to answer items about heroin and opiate use. Of greater concern for purposes of this analysis were the subjects who reported lifetime use but refused to answer questions about use in the past 6 months ( 1 for marijuana, 16 for cocaine, 17 for heroin/opiates, 1 for downers, 46 for hallucinogens, and 3 for tranquilizers).

9. Barbiturates, methaqualone, and propoxyphene should be combined for comparison to self-reported use of "downers"; however, there were no positive EMIT results for either methaqualone (which is no longer produced in the United States) or propoxyphene. EMIT tests for benzodiazapenes were compared to self-reported use of "other tranquilizers, Valium, Librium, Ativan." Phencyclidine is the only hallucinogen test in the EMIT-10 panel; self-reported hallucinogen use ("hallucinogens, LSD, peyote, mescaline, PCP, mushrooms") was compared only to the EMIT phencyclidine test.

\section{References}

Abram, K.M., Teplin, L.A., and McClelland, G.M. 2003. Comorbidity of severe psychiatric disorders and substance use disorders among women in jail. American Journal of Psychiatry 160(5):1007-1010.

Abram, K.M., Teplin, L.A., McClelland, G.M., and Dulcan, M.K. 2003. Comorbid psychiatric disorders in youth in juvenile detention. Archives of General Psychiatry 60(11):1077-1108.

Atkins, D.L., Pumariega, A.J ., Rogers, K., Montgomery, L., Nybro, C., Jeffers, G., and Sease, F. 1999. Mental health and incarcerated youth. I: Prevalence and nature of psychopathology. Journal of Child and Family Studies 8(2):193-204.

Baumgartner, W.A., Hill, V.A., and Blahd, W.H. 1989. Hair analysis for drugs of abuse. Journal of Forensic Sciences 34(6):1433-1453.

Bilchik, S. 1998. Mental Health Disorders and Substance Abuse Problems Among J uveniles. Fact Sheet. Washington, DC: U.S. Department of Justice, Office of J ustice Programs, Office of J uvenile Justice and Delinquency Prevention.

Brook, J.S., Cohen, P., and Brook, D.W. 1998. Longitudinal study of co-occurring psychiatric disorders and substance use. Journal of the American Academy of Child and Adolescent Psychiatry 37(3):322-330.
Brook, J.S., Whiteman, M., and Finch, S.J . 1992. Childhood aggression, adolescent delinquency, and drug use: A longitudinal study. Journal of Genetic Psychology 153(4):369-383.

Brook, J.S., Whiteman, M., Finch, S.J ., and Cohen, P.C. 1996. Young adult drug use and delinquency: Childhood antecedents and adolescent mediators. Journal of the American Academy of Child and Adolescent Psychiatry 35(12):1585-1592.

Catania, J.A., Chitwood, D.D., Gibson, D.R., and Coates, T.J . 1990. Methodological problems in AIDS behavioral research: Influences on measurement error and participation bias in studies of sexual behavior. Psychological Bulletin 108(3):339-362.

Cochran, W.G. 1977. Sampling Techniques. New York, NY: J ohn Wiley \& Sons.

Cocozza, J.J . 1992. Responding to the Mental Health Needs of Youth in the Juvenile J ustice System. Seattle, WA: National Coalition for the Mentally III in the Criminal Justice System.

Cohen, P., Brook, J.S., Cohen, J., Velez, C.N., and Garcia, M. 1990. Common and uncommon pathways to adolescent psychopathology and problem behavior. In Straight and Devious Pathways From Childhood to Adulthood, edited by L.N. Robins and M. Rutter. Cambridge, England: Cambridge University Press.

Cone, E.J . 1997. New developments in biological measures of drug prevalence. In The Validity of Self-Reported Drug Use: Improving the Accuracy of Survey Estimates. NIDA Research Monograph 167, edited by L. Harrison and A. Hughes. Washington, DC: U.S. Department of Health and Human Services.

Council on Scientific Affairs. 1987. Scientific issues in drug testing. Journal of the American Medical Association 312(22):3110-3114.

Craddock, A., Collins, J.J., and Timrots, A. 1994. Drug-Related Crime. Washington, DC: U.S. Department of J ustice, Office of J ustice Programs, Bureau of J ustice Statistics.

Crowe, A.H. 1998. Drug Identification and Testing in the J uvenile J ustice System. Summary. Washington, DC: U.S. Department of J ustice, Office of J ustice Programs, Office of Juvenile J ustice and Delinquency Prevention. 
Dej ong, C., and Wish, E.D. 2000. Is it advisable to urine test arrestees to assess risk of rearrest? A comparison of self-report and urinalysis-based measures of drug use. Journal of Drug Issues 30(1):133-146.

Dembo, R., Shemwell, M., Guida, J., Schmeidler, J., Baumgartner, W., RamirezGarnica, G., and Seeberger, W. 1999. A comparison of self-report, urine sample, and hair sample testing for drug use: A longitudinal study. In Drug Testing Methods: Assessment and Evaluation, edited by T. Mieczkowski. New York, NY: CRC Press.

Dembo, R., Washburn, M., Wish, E.D., Yeung, H., Getreu, A., Berry, E., and Blount, W.R. 1987. Heavy marijuana use and crime among youths entering a juvenile detention center. Journal of Psychoactive Drugs 19(1):47-56.

Dembo, R., Williams, L., Schmeidler, J., and Wothke, W. 1993. A longitudinal study of the predictors of the adverse effects of alcohol and marijuana/hashish use among a cohort of high risk youths. The International Journal of the Addictions 28(11):1045-1083.

Deykin, E.Y., and Buka, S. 1997. Prevalence and risk factors for posttraumatic stress disorder among chemically dependent adolescents. American J ournal of Psychiatry 154 (6):752-757.

Duncan, S.C., Strycker, L.A., and Duncan, T.E. 1999. Exploring associations in developmental trends of adolescent substance use and risky sexual behavior in a highrisk population. Journal of Behavioral Medicine 22(1):21-34.

Elliott, D.S., Huizinga, D., and Menard, S. 1989. Multiple Problem Youth: Delinquency, Substance Use and Mental Health Problems. New York, NY: Springer-Verlag.

Elliott, D.S., and Morse, B.J . 1989. Delinquency and drug use as risk factors in teenage sexual activity. Youth and Society 21(1):32-60.

Fagan, J. 1989. The social organization of drug use and drug dealing among urban gangs. Criminology 27(4):633-667.

Fendrich, M., and Xu, Y. 1994. The validity of drug use reports from juvenile arrestees. The International Journal of the Addictions 29(8):971-985.

Feucht, T.E., Stephens, R.C., and Walker, M.L. 1994. Drug use among juvenile arrestees: A comparison of self-report, urinalysis and hair assay. The Journal of Drug Issues 24(1):99-116.
Golub, A., Johnson, B.D., Taylor, A., and Liberty, H.J . 2002. The validity of arrestees' self-reports: Variations across questions and persons. Justice Quarterly 19(3):477-502.

Gray, T.A., and Wish, E.D. 1998. Substance Abuse Need for Treatment Among Arrestees (SANTA) in Maryland: Youth in the Juvenile J ustice System. College Park, MD: University of Maryland, Center for Substance Abuse Research.

Gray, T.A., and Wish, E.D. 1999. Correlates of underreporting recent drug use by female arrestees. Journal of Drug Issues 29(1):91-106.

Grunbaum, J.A., Kann, L., Kinchen, S.A., Williams, B., Ross, J.G., Lowry, R., and Kolbe, L. 2002. Youth risk behavior surveillance, United States, 2001. Morbidity and Mortality Weekly Report 51(SS-4):1-62.

Harrison, L., and Gfroerer, J. 1992. The intersection of drug use and criminal behavior: Results from the National Household Survey on Drug Abuse. Crime and Delinquency 38(4):422-443.

Harrison, L.D. 1995. The validity of selfreported data on drug use. The J ournal of Drug Issues 25(1):91-111.

Huang, K.H., Watters, J.K., and Case, P. 1988. Psychological assessment and AIDS research with intravenous drug users: Challenges in measurement. J ournal of Psychoactive Drugs 20(2):191-195.

Johnston, L.D., O'Malley, P.M., and Bachman, J.G. 2003. Monitoring the Future: National Survey Results on Drug Use: Overview of Key Findings, 2002. Bethesda, MD: U.S. Department of Health and Human Services, National Institutes of Health, National Institute on Drug Abuse.

Kandel, D., and Yamaguchi, K. 1993. From beer to crack: Developmental patterns of drug involvement. American Journal of Public Health 83(6):851-855.

Kandel, D.B., and Logan, J.A. 1984. Patterns of drug use from adolescence to young adulthood: I. Periods of risk for initiation, continued use, and discontinuation. American Journal of Public Health 74(7):660-666.

Kang, S.Y., Magura, S., and Shapiro, J.L. 1994. Correlates of cocaine/crack use among inner-city incarcerated adolescents. American J ournal of Drug and Alcohol Abuse 20(4):413-429.
Lessler, J.T., and O'Reilly, J.M. 1997. Mode of interview and reporting of sensitive issues: Design and implementation of audio computer-assisted self-interviewing. In The Validity of Self-Reported Drug Use: Improving the Accuracy of Survey Estimates. NIDA Research Monograph 167, edited by L. Harrison and A. Hughes. Washington, DC: U.S. Department of Health and Human Services.

Little, R.J .A., and Schenker, N. 1995. Missing data. In Handbook of Statistical Modeling for the Social and Behavioral Sciences, edited by G. Arminger, C.C. Clogg, and M.E. Sobel. New York, NY: Plenum Press.

Loeber, R., and Hay, D. 1997. Key issues in the development of aggression and violence from childhood to early adulthood. Annual Review of Psychology 48:371-410.

Loeber, R., Stouthamer-Loeber, M., van Kammen, W., and Farrington, D.P. 1991. Initiation, escalation and desistance in juvenile offending and their correlates. Journal of Criminal Law and Criminology 82(1):36-82.

Loeber, R., Stouthamer-Loeber, M., and White, H.R. 1999. Developmental aspects of delinquency and internalizing problems and their association with persistent juvenile substance use between ages 7 and 18. Journal of Clinical Child Psychology 28(3):322-332.

Loeber, R., Wung, P., Keenan, K., Giroux, B., Stouthamer-Loeber, M., van Kammen, W., and Maughan, B. 1993. Developmental pathways in disruptive child behavior. Development and Psychopathology 5(1-2): 103-133.

Lynskey, M.T., and Fergusson, D.M. 1995. Childhood conduct problems, attention deficit behaviors, and adolescent alcohol, tobacco, and illicit drug use. Journal of Abnormal Child Psychology 23(3):281-302.

Magura, S., Kang, S.Y., and Shapiro, J.L. 1995. Measuring cocaine use by hair analysis among criminally-involved youth. J ournal of Drug Issues 25(4):683-701.

Marsteller, F.A., Brogan, D., Smith, I., Ash, P., Daniels, D., Rolka, D., and Falek, A. 1997. The Prevalence of Substance Use Disorders Among J uveniles Admitted to Regional Youth Detention Centers Operated by the Georgia Department of Children and Youth Services. Center for Substance Abuse Treatment Final Report. Available at http://www.behav.com/projects/ CSATFinalReport.html. 
Mason, A.W., and Windle, M. 2002. Reciprocal relations between adolescent substance use and delinquency: A longitudinal latent variable analysis. J ournal of Abnormal Psychology 111(1):63-76.

McCluskey, C.P., Krohn, M.D., Lizotte, A.J ., and Rodriguez, M.L. 2002. Early substance use and school achievement: An examination of Latino, White, and African American youth. Journal of Drug Issues 32(3):921-944.

Mieczkowski, T. 1990. The accuracy of self-reported drug use: An evaluation and analysis of new data. In Drugs, Crime and the Criminal Justice System, edited by R. Weisheit. Cincinnati, $\mathrm{OH}$ : Anderson Publishing.

Mieczkowski, T., Barzelay, D., Gropper, B., and Wish, E. 1991. Concordance of three measures of cocaine use in an arrestee population: Hair, urine, and self-report. J ournal of Psychoactive Drugs 23(3):241-249.

Mieczkowski, T., and Newel, R. 1993. Comparing hair and urine assays for cocaine and marijuana. Federal Probation 57(2):59-67.

Mieczkowski, T., and Newel, R. 1997. Patterns of concordance between hair assays and urinalysis for cocaine: Longitudinal analysis of probationers in Pinellas County, Florida. In The Validity of Self-Reported Drug Use: Improving the Accuracy of Survey Estimates. NIDA Research Monograph 167, edited by L. Harrison and A. Hughes. Washington, DC: U.S. Department of Health and Human Services.

Mieczkowski, T., Newel, R., and Wraight, B. 1998. Using hair analysis, urinalysis, and self-reports to estimate drug use in a sample of detained juveniles. Substance Use and Misuse 33(7):1547-1567.

Miller, M.L., Donnelly, B., and Martz, R.M. 1997. The forensic application of testing hair for drugs of abuse. In The Validity of Self-Reported Drug Use: Improving the Accuracy of Survey Estimates. NIDA Research Monograph 167, edited by L. Harrison and A. Hughes. Washington, DC: U.S. Department of Health and Human Services.

Miller, P.V. 1997. Is "up" right? The National Household Survey on Drug Abuse (The Polls-Review). Public Opinion Quarterly 61(4):627-642.

Moffitt, T.E. 1993a. Adolescence-limited and life-course-persistent antisocial behavior: A developmental taxonomy. Psychological Review 100(4):674-701.
Moffitt, T.E. 1993b. The neuropsychology of conduct disorder. Development and Psychopathology 5(1-2):135-151.

Myers, M.G., Stewart, D.G., and Brown, S.A. 1998. Progression from conduct disorder to antisocial personality disorder following treatment for adolescent substance abuse. American Journal of Psychiatry 155(4):479-485.

Newcomb, M.D., and Bentler, P.M. 1990. Antecedents and consequences of cocaine use: An eight-year study from early adolescence to young adulthood. In Straight and Devious Pathways From Childhood to Adulthood, edited by L.N. Robins and M. Rutter. Cambridge, England: Cambridge University Press.

Pedersen, W., and Hegna, K. 2003. Children and adolescents who sell sex: $A$ community study. Social Science and Medicine 56(1):135-147.

Riley, K.J ., Lu, N.T., and Taylor, B.G. 2000. Drug screening: A comparison of urinalysis results from two independent laboratories. Journal of Drug Issues 30(1):171-186.

Rutter, M. 1996. Transitions and turning points in developmental psychopathology: As applied to the age span between childhood and mid-adulthood. International Journal of Behavioral Development 19(3):603-626.

Shedler, J., and Block, J. 1990. Adolescent drug use and psychological health. American Psychologist 45(5):612-630.

Sickmund, M. Forthcoming. J uveniles in Corrections. Bulletin. Washington, DC: U.S. Department of J ustice, Office of J ustice Programs, Office of J uvenile Justice and Delinquency Prevention.

Snyder, H.N. 2002. Juvenile Arrests 2000. Bulletin. Washington, DC: U.S. Department of J ustice, Office of J ustice Programs, Office of J uvenile J ustice and Delinquency Prevention.

Teplin, L.A. Assessing Alcohol, Drug, and Mental Disorders in Juvenile Detainees. 2001. Fact Sheet. Washington, DC: U.S. Department of J ustice, Office of J ustice Programs, Office of J uvenile J ustice and Delinquency Prevention.

Teplin, L.A., Abram, K.M., McClelland, G.M., Dulcan, M.K., and Mericle, A.A. 2002. Psychiatric disorders in youth in juvenile detention. Archives of General Psychiatry 59(12):1133-1143.
Teplin, L.A., Mericle, A.A., McClelland, G.M., and Abram, K.M. 2003. HIV and AIDS risk behaviors in juvenile detainees: Implications for public health policy. American Journal of Public Health 93(6):906-912.

Turner, C.F., Ku, L., Rogers, S.M., Lindberg, L.D., Pleck, J.H., and Sonenstein, F.L. 1998. Adolescent sexual behavior, drug use, and violence: Increased reporting with computer survey technology. Science 280(5365):867-873.

U.S. Department of Health and Human Services. 1996. Substance Abuse in States and Metropolitan Areas: Model Based Estimates From the 1991-1993 National Household Surveys on Drug Abuse Summary Report. Rockville, MD: U.S. Department of Health and Human Services, Substance Abuse and Mental Health Services Administration, Office of Applied Studies.

U.S. Department of Health and Human Services. 2002. Results From the 2001 National Household Survey on Drug Abuse: Volume III. Detailed Tables (Tables H.57, G.2). Rockville, MD: U.S. Department of Health and Human Services, Substance Abuse and Mental Health Services Administration, Office of Applied Studies.

van den Bree, M.B.M., Svikis, D.S., and Pickens, R.W. 2000. Antisocial personality and drug use disorders-are they genetically related? In The Science, Treatment, and Prevention of Antisocial Behaviors: Application to the Criminal Justice System, edited by D.H. Fishbein. Kingston, NJ : Civic Research Institute.

Visher, C., and McFadden, K. 1991. A Comparison of Urinalysis Technologies for Drug Testing in Criminal Justice. Research in Action. Washington, DC: U.S. Department of J ustice, Office of J ustice Programs, National Institute of J ustice.

Wasserman, G.A., McReynolds, L.S., Lucas, C.P., Fisher, P., and Santos, L. 2002. The voice DISC-IV with incarcerated male youths: Prevalence of disorder. Journal of the American Academy of Child and Adolescent Psychiatry 41(3):314-321.

Windle, M. 1990. A longitudinal study of antisocial behaviors in early adolescence as predictors of late adolescent substance use: Gender and ethnic group differences. J ournal of Abnormal Psychology $99(1): 86-91$. 
Wislar, J.S., and Fendrich, M. 2000. Can self-reported drug use data be used to assess sex risk behavior in adolescents? Archives of Sexual Behavior 29(1):77-89.

Wolff, K., Farrell, M., Marsden, J., Monteiro, M.G., Ali, R., Welch, S., and Strang, J. 1999. A review of biological indicators of illicit drug use, practical considerations and clinical usefulness. Addiction 94(9): 1279-1298.

Yamaguchi, K., and Kandel, D.B. 1984a. Patterns of drug use from adolescence to young adulthood: II. Sequences of progression. American J ournal of Public Health 74(7):668-672.

Yamaguchi, K., and Kandel, D.B. 1984b. Patterns of drug use from adolescence to young adulthood: III. Predictors of progression. American J ournal of Public Health 74(7):673-681.

The research reported in this Bulletin was supported by grant number 1999-JE-FX-1001 from the Office of J uvenile Justice and Delinquency Prevention, Office of J ustice Programs, U.S. Department of J ustice, and grant numbers R01MH54197 and R01MH59463 from the National Institute of Mental Health.

Major funding was also provided by the Centers for Disease Control and Prevention's National Center on Injury Prevention and Control and National Center for HIV, STD, and TB Prevention; the National Institutes of Health's Center on Minority Health and Health Disparities, Office of Rare Diseases, and Office of Research on Women's Health; the National Institute on Alcohol Abuse and Alcoholism; the National Institute on Drug Abuse; the Substance Abuse and Mental Health Services Administration's Center for Mental Health Services, Center for Substance Abuse Prevention, and Center for Substance Abuse Treatment; the Robert Wood Johnson Foundation; and the William T. Grant Foundation.

Additional funds were provided by the Chicago Community Trust, the John D. and Catherine T.
MacArthur Foundation, and the Open Society Institute.

Points of view or opinions expressed in this document are those of the authors and do not necessarily represent the official position or policies of OJJDP or the U.S. Department of J ustice.

\section{Acknowledgments}

The authors of this Bulletin are affiliated with the Department of Psychiatry and Behavioral Sciences, Feinberg School of Medicine, Northwestern University. Gary M. McClelland, Ph.D., is Senior Analyst, Psycho-Legal Studies; Linda A. Teplin, Ph.D., is Owen L. Coon Professor of Psychiatry and Behavioral Sciences and Director, Psycho-Legal Studies; and Karen M. Abram, Ph.D., is Associate Director, Psycho-Legal Studies. The authors thank all of the funding agencies and organizations for their collaborative spirit and steadfast support.

Many individuals contributed to this project. The authors thank OJJDP's Karen Stern, Ph.D, who provided valuable substantive and editorial comments; all project staff, especially Amy M. Lansing, Ph.D., and Amy A. Mericle, Ph.D., who supervised the data collection; Jacques Normand, Ph.D., for insightful comments; and Laura Coats, Kate Elkington, and Erin Gregory for their meticulous library work, editing, and manuscript preparation. The authors greatly appreciate the cooperation of everyone working in the Cook County systems, especially David H. Lux, project liaison. Without the county's cooperation, this study would not have been possible. Finally, the authors thank the study subjects for their time and willingness to participate.

\section{Share With Your Colleagues}

Unless otherwise noted, OJJDP publications are not copyright protected. We encourage you to reproduce this document, share it with your colleagues, and reprint it in your newsletter or journal. However, if you reprint, please cite OJJDP and the authors of this Bulletin. We are also interested in your feedback, such as how you received a copy, how you intend to use the information, and how OJJDP materials meet your individual or agency needs. Please direct your comments and questions to:

\author{
Juvenile Justice Clearinghouse \\ Publication Reprint/Feedback \\ P.O. Box 6000 \\ Rockville, MD 20849-6000 \\ 800-851-3420 \\ 301-519-5600 (fax) \\ Web: tellncjrs.ncjrs.org
}




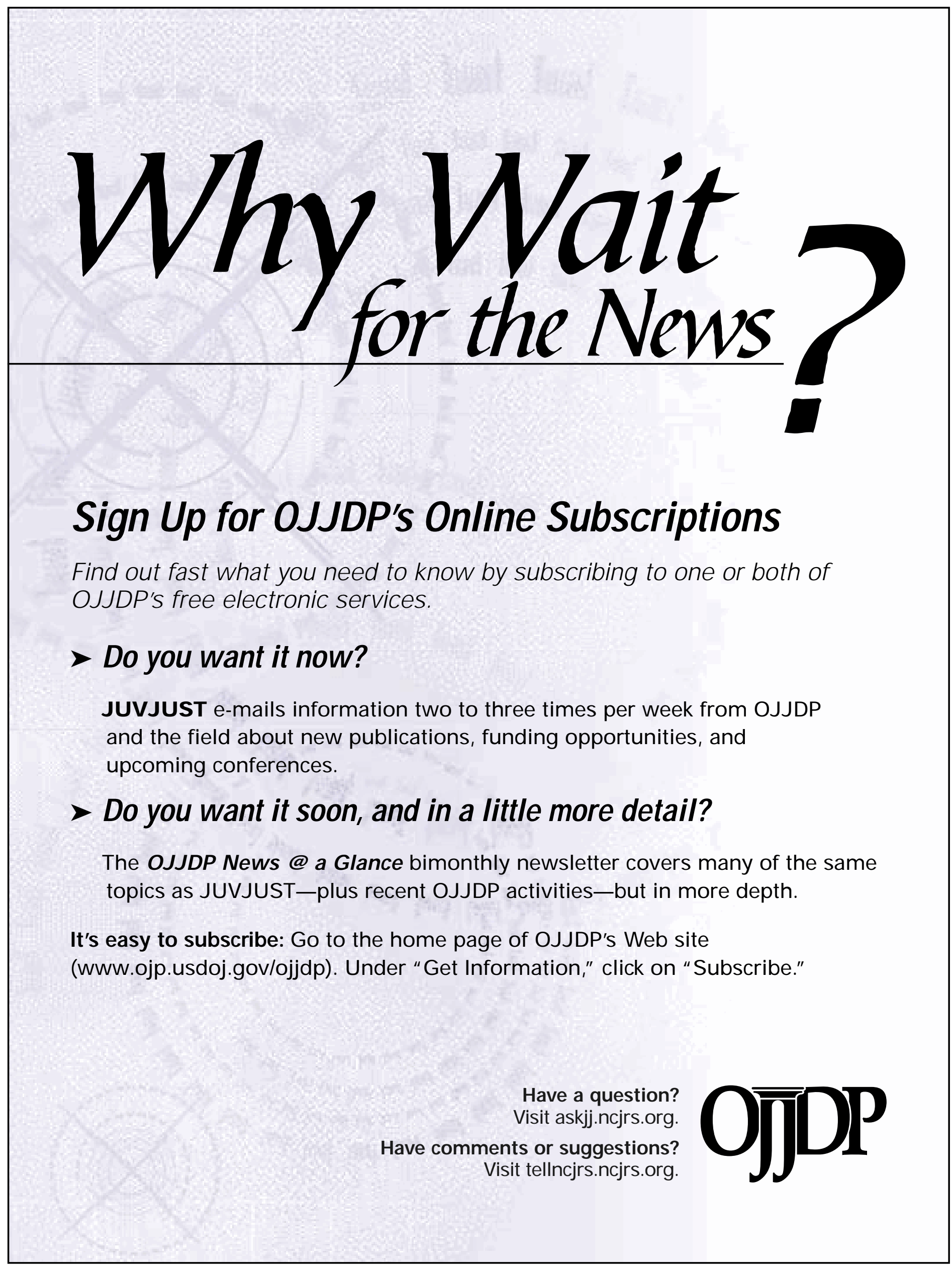


U.S. Department of Justice

Office of Justice Programs

Office of Juvenile Justice and Delinquency Prevention

DOJ/OJJDP

PERMIT NO. G-91

Washington, DC 20531

Official Business

Penalty for Private Use $\$ 300$ 